Check for updates

Cite this: RSC Adv., 2017, 7, 28298

Received 11th May 2017

Accepted 23rd May 2017

DOI: $10.1039 / \mathrm{c} 7 \mathrm{ra05349e}$

rsc.li/rsc-advances

\section{Efficient total synthesis of neocryptolepine and synthetic access to 6-methylquinindoline from a common intermediate $\uparrow$}

\author{
María V. Méndez, (D) Daniel A. Heredia, (ID $†$ Enrique L. Larghi, (D) Andrea B. J. Bracca \\ and Teodoro S. Kaufman (D)*
}

A convenient approach toward the indoloquinolines neocryptolepine and 6-methylquinindoline from a common intermediate, is reported. Both sequences, designed for maximum use of accessible reagents and robust conditions, are straightforward and efficient. They involved the amidation of 2aminobenzaldehyde (prepared by iron-mediated reduction of 2-nitrobenzaldehyde) with 2nitrophenylacetic acid, followed by a $\mathrm{K}_{2} \mathrm{CO}_{3}$-assisted cyclization to form a 3-(2-nitrophenyl)quinolin-2one as the common precursor. $\mathrm{Me}_{2} \mathrm{CO}_{3}$-mediated $\mathrm{N}$-methylation of the lactam, reduction of the nitro moiety and final cyclization resulted in 55\% overall yield of neocryptolepine, whereas cyclocondensation and $\mathrm{N}$-methylation afforded $79 \%$ overall yield of 6 -methyl quinindoline. Thus, the sequences toward the targets entailed two $\mathrm{POCl}_{3}$-promoted $\mathrm{C}-\mathrm{N}$ bond forming reactions, two Fe-mediated nitro group reductions and two base-promoted transformations.

\section{Introduction}

Cryptolepis sanguinolenta (Lindl.) Schlachter (Periplocaceae) is a climbing vine, which grows in West and Central Africa, where it is locally known as nibima, kadze or gangamau, and has served Ghanian traditional healers as a folk medicine since ancestral times. The decoction of the roots of this plant have been used in the therapy against various fevers, including malaria, but also as treatment for hypertension, hepatitis, jaundice and inflammation. ${ }^{1}$

The systematic phytochemical examination of C. sanguinolenta demonstrated that it is a rich source of indoloquinolines. The latter are a small and unique family of alkaloids, which feature two differently fused ring systems, an indole and a quinoline. ${ }^{2}$

Some of its monomeric members are neocryptolepine (1) ${ }^{3 a}$ cryptolepine (2), ${ }^{3 b, c}$ quindoline (3), ${ }^{3 d}$ quindolinone (4), ${ }^{3 e}$ cryptosanguinolentine (5),,$^{4 a}$ 11-isopropylcryptolepine (6), ${ }^{4 b, c}$ cryptolepinone (7), ${ }^{4 d}$ and quinindoline (8), as shown in Fig. $1 .^{5 a}$ Several dimeric alkaloids are also known, including biscryptolepine (9) ${ }^{5 b}$ cryptoquindoline, ${ }^{4 d}$ cryptolepicarboline, ${ }^{6 a}$ cryptospirolepine ${ }^{6 b}$ quindolinocryptotackieine ${ }^{6 c}$ and cryptomisrine. ${ }^{6 d}$

Instituto de Química Rosario (CONICET-UNR), Suipacha 531, S2002LRK, Rosario, SF, Argentina. E-mail: kaufman@iquir-conicet.gov.ar; Fax: +54-341-4370477 ext. 105; Tel: $+54-341-4370477$ ext. 105

$\dagger$ Electronic supplementary information (ESI) available: Selected spectra of intermediates and final product. See DOI: 10.1039/c7ra05349e

\$ Present address: Departamento de Química, Universidad Nacional de Río Cuarto, Agencia Postal No. 3, X5804BYA, Río Cuarto, Argentina.

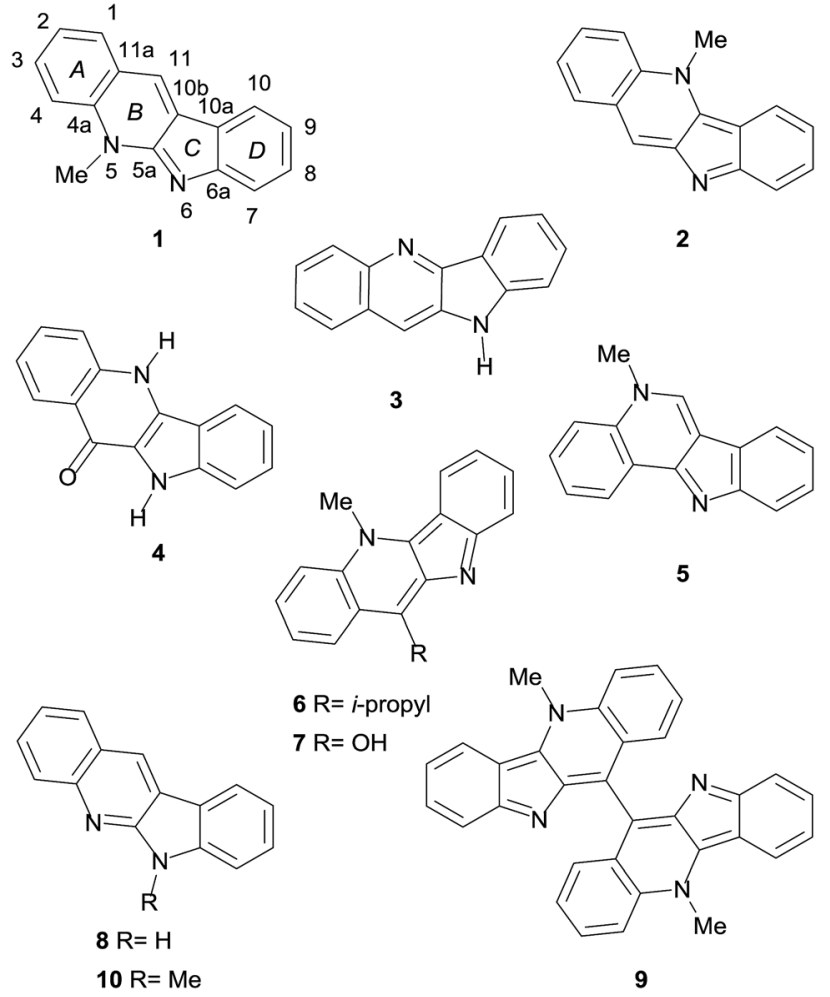

Fig. 1 Chemical structures of representative examples of the indoloquinoline alkaloids. Neocryptolepine (cryptotackieine, 1), cryptolepine (2), quindoline (3), quindolinone (4), cryptosanguinolentine (5), 11isopropylcryptolepine (6), cryptolepinone (7), quinindoline (8), biscryptolepine (9) and the unnatural 6-methylquinindoline (10). 
Although most of the indoloquinolines have been isolated from this shrub, there are some scattered reports disclosing additional sources of these heterocycles, including Cryptolepis triangularis N. E. Br., Sida acuta Burm. (Malvaceae), Microphilis guyanensis (A. DC) Pierre (Sapotaceae), Justicia betonica (Acanthaceae) and Genipa americana L. (Rubiaceae). ${ }^{7}$

The isolation of neocryptolepine (1) from the bark of the roots of C. sanguinolenta was reported independently and almost simultaneously in 1996, by the groups of Schiff, who termed the new alkaloid cryptotakieine, ${ }^{3 a}$ and Pieters. ${ }^{5 b}$ Curiously, this is not the only case of dual naming of the same alkaloid isolated from this plant. ${ }^{6 c}$

In both instances, the structure of the natural product was elucidated through extensive NMR spectroscopic analyses, including $2 \mathrm{D}$ experiments, ${ }^{5 b}$ which conclusively proved that it is an isomer of cryptolepine and isocryptolepine, ${ }^{4 a}$ and unambiguously defined the site of $N$-methylation.

Interestingly enough, the structure of $\mathbf{1}$ conceited great interest and its synthesis was already described long before its isolation from natural sources. ${ }^{\text {sa-d }}$ Furthermore, the natural product, whose skeleton bears key common features with those of the communesins, ${ }^{8 e-g}$ demonstrated to display cytotoxic and antimalarial activity, also acting as a DNA intercalator.

We have recently reviewed both, the synthesis and the biological activities of neocryptolepine, ${ }^{9}$ and classified the total syntheses of 1 in three groups, according to the compounds employed as key starting materials for their syntheses; these included those derived from indoles, ${ }^{10}$ quinolines ${ }^{11}$ and benzenoids. $^{12}$

In this way, we found out that after its isolation the natural product has also attracted an unusually great amount of attention from the organic synthetic community, to the extent that approximately 15 total syntheses and 8 formal total syntheses ${ }^{13}$ of it have been reported to date; further, most of them have used quinindoline (8) as key intermediate. ${ }^{10 a-c, 11 a, 12 a-f, 13 b-h}$ However, in spite of the exceptionally important number of published total syntheses of $\mathbf{1}$, neither of them has been designed to take into account the care for the environment.

The development of efficient and versatile synthetic sequences toward complex molecules has become one of the most relevant goals of modern organic chemistry. Therefore, herein we wish to report a short total synthesis of neocryptolepine (1), which involves a new strategic approach for building the tetracycle and contains environmentally benign stages.

In addition, a synthesis of the isomeric 6-methylquinindoline (10) is also disclosed, employing a common synthetic intermediate and the same operational principles for both targets. Interestingly, there are only four previous records on the preparation of the non-natural compound $1 \mathbf{1 0}^{14}$

\section{Results and discussion}

Our approach toward 1 relied on the retrosynthetic analysis shown in Scheme 1. The initial rational disconnection was made on the $N-5$ substituent (Route a), assuming that it could

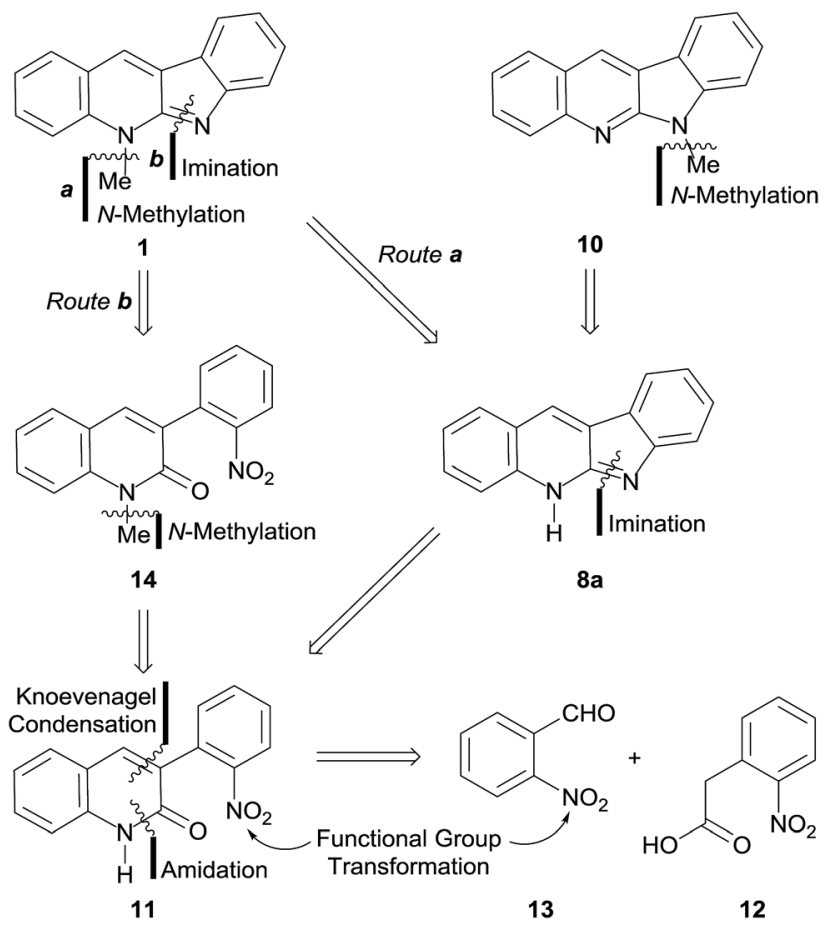

Scheme 1 Retrosynthetic analyses of neocryptolepine (1) and 6methyl quinindoline (10).

be accessed by $N$-methylation under eco-conscious conditions, instead of using the more conventional but less safe $\mathrm{Me}_{2} \mathrm{SO}_{4}$ or MeI as alkylating agents, as in all previous syntheses. This revealed the synthetic need of $\mathbf{8 a}$, the tautomer of quinindoline (8), which was conjectured as accessible through an intramolecular imination of the lactam 11.

In turn, the key intermediate $\mathbf{1 1}$ was structurally simplified by performing two successive strategic disconnections of its heterocyclic ring, which uncovered an amide precursor and further revealed 2-nitrophenylacetic acid (12) and 2-nitrobenzaldehyde (13), as the most logical starting materials.

On the other hand, a second set of disconnections was also deemed possible, by merely reversing the order of the initial disconnections. This strategy, which already proved fruitful in our hands ${ }^{15}$ conveniently furnished an alternative path (Route b) toward the target.

In this case, the first disconnection was performed on the $\mathrm{C}=\mathrm{N}$ bond of the five-membered ring, unearthing 14 , which was subjected to the retrosynthetic fission of the $N$-methyl bond, exhibiting the precursor lactam $\mathbf{1 1}$ as the common intermediate of both retrosynthetically proposed routes.

In both cases, it was foreseen that functional group transformations would be required in order to accommodate the readily available nitro-derivatives proposed as starting materials to the needs of the synthetic sequences. However, this would be rewarded by completely avoiding the need of protective groups.

In this analysis, it was also hypothesized that $\mathbf{8 a}$ could also become a suitable precursor of $\mathbf{1 0}$, provided appropriately selective $N$-methylation conditions could be found. 
The Route a, which pivoted on an $\mathrm{A} \rightarrow \mathrm{AD} \rightarrow \mathrm{ABD} \rightarrow \mathrm{ABCD}$ ring forming sequence, was initially explored. To that end, despite the required 2-aminobenzaldehyde $\mathbf{1 5}$ is commercially available, its elevated cost and reportedly high instability ${ }^{16}$ prompted for its synthesis in situ, which was undertaken as the first task.

Among the various protocols which were examined, the most successful one proved to be that which uses metallic iron in a refluxing hydro-alcoholic $(10: 90 \mathrm{v} / \mathrm{v})$ medium, in the presence of a mild acid catalyst such as $\mathrm{NH}_{4} \mathrm{Cl} .{ }^{17}$ Under these conditions, $96 \%$ of $\mathbf{1 5}$ was easily obtained, with no sensitive drop in yields when the reduction was performed on a gram scale (Scheme 2).

However, it was found that special care had to be placed in removing even the smallest traces of iron and its salts, as any of both promoted self-condensation of the product during concentration of the solutions containing the ortho-aminoaldehyde, through Schiff base formation.

After securing the supply of 15, its amidation with acid $\mathbf{1 2}$ was scrutinized, in a task that proved to be non-trivial. The use of carbodiimide coupling agents (DCC, EDCI) afforded only moderate yields of 16, partly due to self-condensation of $12,{ }^{18 a}$ but also because of its rather poor solubility. On the other hand, the use of a mixed carboxylic anhydride strategy in THF (Table 1), with (Boc) ${ }_{2} \mathrm{O}$ as activating agent and $\mathrm{Et}_{3} \mathrm{~N}$ (entry 1 ) or pyridine (entries $2-4$ ) as bases ${ }^{18 b}$ produced at best $26 \%$ of the expected amide $\mathbf{1 6 .}$
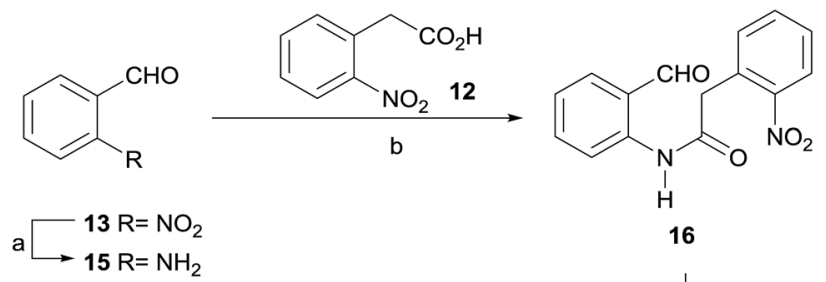

$15 \mathrm{R}=\mathrm{NH}$<smiles>[R]Nc1ccccc1-c1cc2ccccc2[nH]c1=O</smiles>

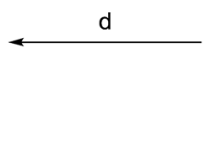

$17 \mathrm{R}=\mathrm{Ac}$

16

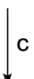

$18 \mathrm{R}=\mathrm{H}$

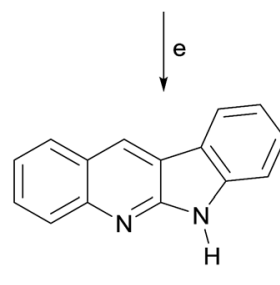

8
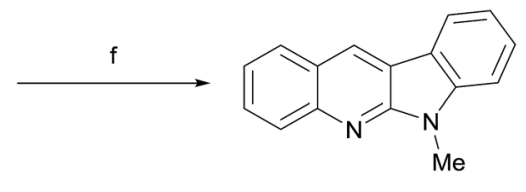

10

Scheme 2 Reagents and conditions: (a) $\mathrm{Fe}, \mathrm{NH}_{4} \mathrm{Cl}$, EtOH- $\mathrm{H}_{2} \mathrm{O}(9: 1$, $\mathrm{v} / \mathrm{v})$, reflux, $2 \mathrm{~h}(96 \%)$; (b) $\mathrm{POCl}_{3}$, pyridine, $\mathrm{DMF}$ (cat.), 12, $\mathrm{PhCF}_{3}$, r.t., $3 \mathrm{~h}$ (97\%); (c) $\mathrm{K}_{2} \mathrm{CO}_{3}, \mathrm{DMF}, 100{ }^{\circ} \mathrm{C}, 1 \mathrm{~h}(99 \%) ;($ d) $\mathrm{Fe}, \mathrm{AcOH}$, reflux, overnight (17, 99\%) or $\mathrm{Fe}, \mathrm{NH}_{4} \mathrm{Cl}, \mathrm{EtOH}-\mathrm{H}_{2} \mathrm{O}(9: 1, \mathrm{v} / \mathrm{v})$, reflux, 2 h $(18,99 \%)$; (e) $\mathrm{Py} \cdot \mathrm{HCl}, 240{ }^{\circ} \mathrm{C}, 10 \mathrm{~min}(70 \%$ from $17 ; 93 \%$ from 18$)$ or $\mathrm{POCl}_{3}, \mathrm{MeCN}$, $90{ }^{\circ} \mathrm{C}$ (94\% from 18); (f) $\mathrm{DMC}, \mathrm{MgO}, \mathrm{MW}\left(170{ }^{\circ} \mathrm{C}\right), 30 \mathrm{~min}(89 \%)$.
The outcomes of these reactions were similar when carried out either in two stages (activation and condensation) or in a single stage (mixing all the reactants together at once). No substantially better performance was achieved with $\mathrm{Ac}_{2} \mathrm{O}$ in toluene (entry 5). ${ }^{23 a}$

In the pharmaceutical industry, acid chlorides are by far the most common acylating agents for the preparation of drug candidate molecules, ${ }^{18 c}$ with oxalyl chloride and $\mathrm{SOCl}_{2}$ being preferred based on criteria of wide utility, scalability and greeneness. ${ }^{18 d}$ However, attempts at formation of the acid chloride with oxalyl chloride in toluene, ${ }^{18 e}$ and its further condensation with aniline $\mathbf{1 5}$ afforded at most $34 \%$ yield of $\mathbf{1 6}$, when pyridine was used as base (entry 6).

This result was substantially improved when $\mathrm{SOCl}_{2}$ (entries 7 and 8) was used, and yields as high as $50 \%$ could be obtained with pyridine as base. Surprisingly, however, no better yields were initially obtained when the less volatile $\mathrm{POCl}_{3}$ was employed as activating agent either in two-stage (entry 9) or single-stage (entry 10) setups. ${ }^{18 f}$

An in-tube NMR monitoring experiment revealed that the first stage required catalytic amounts of DMF to speed up the formation of the acid chloride $\left(\mathrm{ArCH}_{2} \mathrm{COCl}\right.$ as a singlet at $\delta_{\mathrm{H}}=$ $4.54 \mathrm{ppm})$. The reaction resulted in $\mathrm{H}_{3} \mathrm{PO}_{4}$ as the only byproduct $\left(\delta^{31} \mathrm{p}=0.00\right.$ vs. $\delta^{31} \mathrm{p}=3.19 \mathrm{ppm}$ for $\left.\mathrm{POCl}_{3}\right)$ after complete conversion of the acid $\mathbf{1 2}$ was achieved; however, other phosphorus-containing reaction intermediates were also observed. ${ }^{19}$

Interestingly, the success of this experiment also confirmed that $\mathrm{POCl}_{3}$ afforded a transformation with better atom economy than $\mathrm{SOCl}_{2}$, minimizing reagent utilization and byproduct generation, and that the low solubility of $\mathbf{1 2}$ in toluene adversely affected the reaction performance.

It was also observed that addition of the base $\left(\mathrm{Et}_{3} \mathrm{~N}\right.$ or pyridine) all at once to the preformed acid chloride caused an almost immediate destruction of the latter, whereas dropwise or partial addition promoted self-condensation of the aminoaldehyde 15, compromising product yields.

The effects of overcoming the solubility problem on the yields was tested in a small-scale experiment run in $\mathrm{CH}_{2} \mathrm{Cl}_{2}$, where we were pleased to discover that this modification afforded $93 \%$ of the amide $\mathbf{1 6}$ (entry 11 ).

An eco-acceptable solution was implemented using benzotrifluoride as solvent replacement, which furnished $97 \%$ of the expected product (entry 12 ).$^{20}$ The optimally accessed amide 16 was then submitted to an intramolecular Knoevenagel-type cyclization under $\mathrm{K}_{2} \mathrm{CO}_{3}$ promotion, ${ }^{21}$ to afford $99 \%$ of the desired 3-arylquinolone 11.

An attempt to reach the key intermediate 8 through a one pot reduction of the nitro moiety and subsequent in situ cyclization of the resulting product, was next made. Hence, $\mathbf{1 1}$ was exposed to iron powder in refluxing AcOH. However, this resulted in the generation of acetanilide derivative 17, which could not be cyclized with $\mathrm{POCl}_{3}{ }^{11 b, 22}$ but afforded $70 \%$ of the expected product $\mathbf{8}$ upon exposure to molten pyridinium hydrochloride $(\mathrm{Py} \cdot \mathrm{HCl}){ }^{23}$

An effort to improve the performance of the synthesis was made, under the hypothesis that the free aniline should be a more suitable substrate for the cyclocondensation. Therefore, 
Table 1 Optimization of the amidation of acid 12 with aniline 15<smiles>Nc1ccccc1C=O</smiles>

15

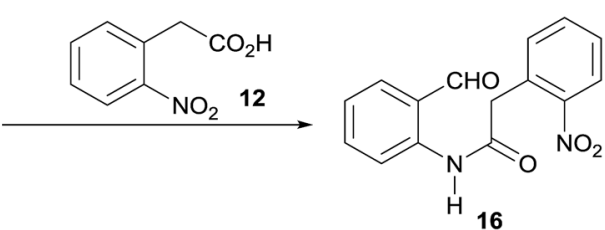

Coupling reagents (equivalents), temperature, time

\begin{tabular}{|c|c|c|c|c|}
\hline Entry no. & Solvent & Step 1 & Step 2 & Yield $^{a}(\%)$ \\
\hline 2 & THF & $(\mathrm{Boc})_{2} \mathrm{O}, \mathrm{MgCl}_{2}$, r.t., $1.2 \mathrm{~h}$ & Pyridine (2.0), reflux, $15 \mathrm{~h}$ & 26 \\
\hline 5 & PhMe & $\mathrm{Ac}_{2} \mathrm{O}, \mathrm{Et}_{3} \mathrm{~N}, 90^{\circ} \mathrm{C}, 48 \mathrm{~h}$ & & 28 \\
\hline 6 & PhMe & $(\mathrm{COCl})_{2}(2.0), \mathrm{DMF}$ (cat.), $0{ }^{\circ} \mathrm{C}$ to r.t. & Pyridine $(3.0), 40^{\circ} \mathrm{C}, 2.5 \mathrm{~h}$ & 34 \\
\hline 7 & PhMe & $\mathrm{SOCl}_{2}(1.85), \mathrm{DMF}$ (cat.), $50{ }^{\circ} \mathrm{C}, 5 \mathrm{~h}$ & $\mathrm{Et}_{3} \mathrm{~N}(3.0), 50{ }^{\circ} \mathrm{C}, 28 \mathrm{~h}$ & 36 \\
\hline 10 & PhMe & $\mathrm{POCl}_{3}(0.7)$, DMF (cat.), pyridine (3.0), r.t., $48 \mathrm{~h}$ & & 35 \\
\hline 11 & $\mathrm{CH}_{2} \mathrm{Cl}_{2}$ & $\mathrm{POCl}_{3}(0.7)$, DMF (cat.), pyridine (3.0), r.t., $15 \mathrm{~h}$ & & 93 \\
\hline 12 & $\mathrm{PhCF}_{3}$ & $\mathrm{POCl}_{3}(0.7)$, DMF (cat.), pyridine (3.0), r.t., $3 \mathrm{~h}$ & & 97 \\
\hline
\end{tabular}

compound $\mathbf{1 1}$ was reduced with iron powder in $\mathrm{EtOH}-\mathrm{H}_{2} \mathrm{O}$, as for the synthesis of $\mathbf{1 5}$, providing to our delight the required intermediate aniline $\mathbf{1 8}$ in essentially quantitative yield.

Based on the previous experience, the use of the high temperature ionic liquid $\mathrm{Py} \cdot \mathrm{HCl}$ was deemed the most suitable approach toward cyclization of $\mathbf{1 8}$, which cleanly afforded the thermodynamic (more stable) amidine isomer 8 in $93 \%$ yield. The latter is a natural product, isolated from coal tar pitch and from Justicia betonica, ${ }^{\mathbf{5 a}, 24}$ which has been repeatedly synthesized. ${ }^{25}$ However, quite a similar result (94\% yield of 8) was obtained employing $\mathrm{POCl}_{3}$ as cyclization agent, under milder conditions.

Next, the final $N$-methylation stage was approached, with the use of a MgO-catalyzed methylation with dimethyl carbonate (DMC) ${ }^{26}$ The latter is a versatile and safe replacement of more hazardous alkylating agents, such as $\mathrm{MeI}, \mathrm{Me}_{2} \mathrm{SO}_{4}$ and MeOTf, which have been widely used in the field of indoloquinoline chemistry; further, it does not produce harmful reaction waste.

However, and not without surprise, we were able to observe the smooth generation of a single less polar compound, in $89 \%$ yield, which turned out to be 6-methyl quinindoline (10), the unnatural isomer of $\mathbf{1}$ and one of our synthetic targets. Other alternatives were explored, including the use of DBU as catalyst; however, all of them met with the same result. ${ }^{27}$

The formation of $\mathbf{1 0}$ as the sole reaction product was unequivocally assessed by exhaustive examination of the ${ }^{1} \mathrm{H}$ and ${ }^{13} \mathrm{C}$ NMR spectra of the product, and their comparison with authentic spectra and literature data of both, $\mathbf{1}$ and $\mathbf{1 0 .}$

The diagnostic ${ }^{1} \mathrm{H}$ NMR resonance of the methyl moiety of $\mathbf{1 0}$ in $\mathrm{CDCl}_{3}$ was seen at $\delta 4.02 \mathrm{ppm}$, in agreement with the literature $\left[\delta 3.99,{ }^{14 b} 3.97\right.$ (ref. $14 b$ ) and 3.82 (ref. 14a) ppm], whereas the 5-methyl group of the natural product was reported to resonate as a singlet in the narrow range of $\delta 4.34 \pm 0.03 \mathrm{ppm}$. Interestingly, this analysis also revealed that at least once, these subtle spectral differences between $\mathbf{1}$ and $\mathbf{1 0}$ resulted in a case of incorrect assignment of product identity. ${ }^{14 b}$

Although the intimate details of the mechanism of this unique transformation remain unknown, an operating mechanistic picture for the DBU-mediated transformation like that shown in Scheme 3 can be drawn, based on various literature precedents.

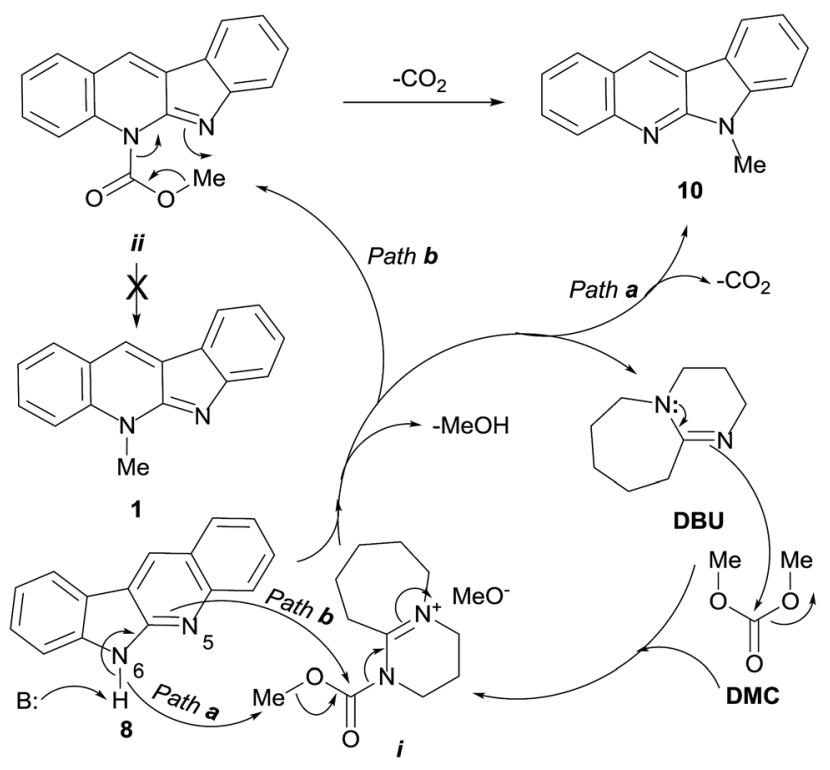

Scheme 3 Proposed pathways for the DMC-mediated methylation of quinindoline (8), under DBU promotion, resulting exclusively in 6methylquinindoline (10). 
Accordingly, it is reasonable to assume that the catalytic cycle is initiated by the nucleophilic attack of DBU to DMC, a recognized ambident electrophile. ${ }^{28}$ As previously proposed, at the reaction temperature $\left(90^{\circ} \mathrm{C}\right)$ this could generate the ion pair intermediate i. ${ }^{27}$ In turn, this highly activated species could act as methyl (Path a) or methoxycarbonyl (Path b) transferring agent. ${ }^{29}$

Quinindoline (8) is also an ambident nucleophile, which offers two possible sites of alkylation ( $N-5$ and $N-6)$. It can be postulated that in the presence of DBU as base, due to the relative basicities of both heteroatoms of the amidino moiety, $N-6$ may become the preferred position for the reaction (Path a), resulting in the methylated tetracycle $\mathbf{1 0}$, with concomitant loss of $\mathrm{CO}_{2}$ and $\mathrm{MeOH}$, and regeneration of the catalyst.

Factors controlling analogous processes in other amidines have been discussed, and seem to be in agreement with the above findings. ${ }^{30}$ Further, there is ample precedent in the chemistry of indoloquinolines indicating that in unsubstituted derivatives, selective methylation of the pyridine ring takes place by reaction with $\mathrm{MeI}$ and $\mathrm{Me}_{2} \mathrm{SO}_{4}$ alone, whereas in the presence of bases, alkylation of the pyrrole ring becomes predominant or exclusive. ${ }^{31}$

Alternatively, it can be conjectured that the highly activated species i could act as a methoxycarbonyl transferring agent (Path b) ${ }^{29}$ Therefore, in the presence of quinindoline (8), this should result in the carbamate intermediate ii, formed under assistance of $N-6$ of the heterocycle 8, with concomitant loss of $\mathrm{MeOH}$ and regeneration of the catalyst.

It has been shown that methylcarbamates cannot be converted into the related $N$-methyl derivatives by mere heating. This would preclude the direct access of $\mathbf{1}$ from ii. However, intermediate ii could undergo an intramolecular thermallyassisted extrusion of $\mathrm{CO}_{2}$ that would result in the observed compound 10. Analogous mechanisms have been proposed for the organic base-mediated alkylation of other functional groups bearing acidic protons. ${ }^{32}$ On the other hand, the intermediacy of carbamates in these reactions has some precedents, and mixtures of carbamates and $N$-methyl derivatives have been obtained in many occasions. ${ }^{33}$

The exquisite and unusual selectivity of this $N-6$ methylation along Path b could also find an explanation based on the hardsoft acid-base theory. In this context, the formation of intermediate ii could be understood as the typical result of the attack of a hard nucleophile $(N-5)$ to the hard carbonyl centre. This would bring about the production of a soft nucleophile and presumably lower the $\mathrm{p} K_{\mathrm{a}}$ of $N-6$, turning it capable of becoming involved in an intramolecular attack on the soft methyl group, to afford 10, with concomitant release of $\mathrm{CO}_{2}$.

Regardless the fine details of the mechanism, the reactivity of the nitrogen atoms of quinindoline is quite special and it has been shown that it can be modified by minor structural variations on the rings. ${ }^{34 a, b}$ Accordingly, the work of Mastalarz and coworkers is illustrative of the different outcomes of $\mathrm{N}$-methylations of a substituted indoloquinoline with $\mathrm{Me}_{2} \mathrm{SO}_{4}$, MeI and $\mathrm{DMC},{ }^{34 c}$ and in agreement with our findings.

Ultimately, compound $\mathbf{1 0}$ was one of the projected synthetic targets and the reaction of $\mathbf{8}$ with DMC demonstrated to provide

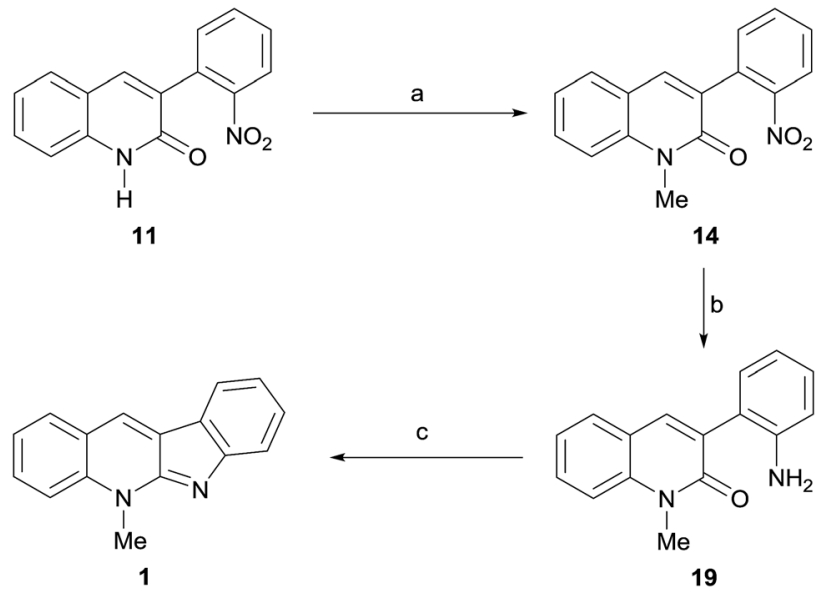

Scheme 4 Reagents and conditions: (a) DMC, DMF, DBU, $90{ }^{\circ} \mathrm{C}$, overnight (95\%); (b) Fe, $\mathrm{NH}_{4} \mathrm{Cl}, \mathrm{EtOH}-\mathrm{H}_{2} \mathrm{O}$ (9 : 1, v/v), reflux, $3 \mathrm{~h}$ (96\%); (c) $1 . \mathrm{POCl}_{3}, \mathrm{MeCN}^{\circ} 90^{\circ} \mathrm{C}$, overnight; 2 . DIPEA, $120^{\circ} \mathrm{C}$, overnight $(63 \%)$.

the suitably selective $\mathrm{N}$-methylation conditions looked for in the planning stage. Therefore, focusing back on $\mathbf{1}$, the unexpected outcome of the DMC-mediated methylation of $\mathbf{8}$ prompted us to explore the Route b. Here, it became clear that efforts should be placed on transforming the lactam 11 into the natural product, with a view of simplifying the proposed synthesis.

Toward this end, the lactam was suspended in DMC to which a small amount of DMF was added in order to favor its solubility, and exposed to methylation under DBU catalysis. Delightfully, $95 \%$ of the more soluble $N$-methyl lactam 14 was obtained after heating overnight at $90{ }^{\circ} \mathrm{C}$ (Scheme 4). In turn, the second iron-mediated reduction of a nitro moiety was put in practice under the previously used conditions, affording $96 \%$ of the known aniline derivative $19 .{ }^{11 b}$ Finally, exposure of 19 to $\mathrm{POCl}_{3}$ in $\mathrm{MeCN}$, to form a reactive 2-chloroquinolinium intermediate, followed by treatment of the latter with DIPEA, gave the expected tetracycle 1 in $63 \%$ yield. Its spectroscopic data were in full agreement with those of the literature for neocryptolepine.

An original aspect is that the syntheses feature the environmentally benign DMC as methylating agent which, acting in two different scenarios, provides two different outcomes. Further, to the best of our knowledge, this is the first total synthesis of 1 which employs this alkylating agent; previous sequences relied on methylation steps with MeI or $\mathrm{Me}_{2} \mathrm{SO}_{4}$, which severely compromised their eco-friendliness.

\section{Conclusions}

We have developed very simple and efficient 5-step strategies for the total synthesis of the natural indoloisoquinoline alkaloid neocryptolepine (55\% overall yield) and its non-natural isomer 6-methylquinindoline ( $79 \%$ overall yield) from 2-nitro phenylacetic acid and 2-aminobenzaldehyde, employing a 3-aryl quinolin-2-one common precursor.

The syntheses were designed from the onset to be as straightforward and reagent-economic as possible, while 
complying with an original key retrosynthetic disconnection $(\mathrm{C}-$ 11-C-10b). This is the first synthetic solution toward both targets featuring this strategy. Further, both targets were synthesized employing essentially the same reagents but inverting the order of some reaction steps, and unlike most previous approaches, the syntheses employed readily available starting materials and reagents.

The synthesis of neocryptolepine involved a couple of convenient iron-mediated reductions of aromatic nitro moieties to their corresponding anilines and two $\mathrm{POCl}_{3}$-assisted $\mathrm{C}-\mathrm{N}$ bond forming reactions. A base-assisted cyclization and a basepromoted $\mathrm{N}$-methylation with dimethyl carbonate (DMC) completed the set of reactions.

The strategy toward both heterocycles, which did not resort to the use of protecting groups, employed robust reactions and maximized the use of comparatively benign solvents. Being modular, differently substituted $o$-amino benzaldehydes and $o$ nitrophenylacetic acids could be used to prepare analogs. Hence, this contribution should pave the way for the elaboration of more complex analogs of the natural product and its congeners.

\section{Experimental section}

\section{General information}

All the reactions were carried out under dry nitrogen or argon atmospheres, employing oven-dried glassware. Anhydrous THF and $\mathrm{Et}_{2} \mathrm{O}$ were obtained from a $\mathrm{M}$. Braun solvent purification and dispenser system; anhydrous DMF was obtained by heating the PA grade product over $\mathrm{BaO}$ for $4 \mathrm{~h}$, followed by distillation under reduced pressure; anhydrous pyridine was prepared by sequential storage of the product for 7 days on $\mathrm{NaOH}$ pellets and atmospheric pressure distillation; anhydrous $\mathrm{Et}_{3} \mathrm{~N}$ was prepared by distillation of the commercial product from $\mathrm{CaH}_{2}$; anhydrous solvents were stored in dry Young ampoules. EtOH refers to the $96^{\circ}$ product. All other reagents were used as received.

Flash column chromatographies were carried out with Merck's silica gel $60 \mathrm{H}$. The elutions were carried out with hexane/EtOAc or EtOAc/EtOH mixtures, under positive pressure and employing gradient of solvent polarity techniques. All new compounds gave single spots on TLC plates (silica gel $60 \mathrm{GF}_{254}$ ) run in different hexane/EtOAc and EtOAc/EtOH solvent systems.

The chromatographic spots were detected by exposure to $254 \mathrm{~nm}$ UV light, followed by spraying with Dragendorff reagent (Munier and Macheboeuf modification), ${ }^{35}$ or with ethanolic $p$ anisaldehyde/sulfuric acid reagent and final careful heating of the plates for improving selectivity.

\section{Apparatus}

The melting points were measured on an Ernst Leitz Wetzlar model 350 hot-stage microscope and are reported uncorrected. The IR spectra were recorded with a Shimadzu Prestige 21 spectrophotometer, as solid dispersions in $\mathrm{KBr}$ disks or as thin films held between $\mathrm{NaCl}$ cells. The NMR spectra were acquired at $300.13\left({ }^{1} \mathrm{H}\right), 121.5 \mathrm{MHz}\left({ }^{31} \mathrm{P}\right)$ or $75.48\left({ }^{13} \mathrm{C}\right) \mathrm{MHz}$ on a Bruker Avance spectrometer in $\mathrm{CDCl}_{3}$, unless stated otherwise. The peak for $\mathrm{CHCl}_{3}$ in $\mathrm{CDCl}_{3}\left(\delta_{\mathrm{H}}=7.26 \mathrm{ppm}\right), \mathrm{H}_{3} \mathrm{PO}_{4}\left(\delta^{31} \mathrm{P}=0.00\right.$ $\mathrm{ppm})$ and the signal of $\mathrm{CDCl}_{3}\left(\delta_{\mathrm{C}}=77.0 \mathrm{ppm}\right)$ were used as the corresponding internal standards. Chemical shifts are reported in parts per million on the $\delta$ scale and $J$-values are given in Hertz. In special cases, ${ }^{31} \mathrm{P}$ NMR, DEPT and 2D-NMR experiments (COSY, HMBC and HMQC) were also employed. Pairs of signals marked with asterisk (*) indicate that their assignments may be exchanged. The high-resolution mass spectra were obtained with a Bruker MicroTOF-Q II instrument (Bruker Daltonics, Billerica, MA). Detection of the ions was performed in electrospray ionization, positive ion mode. Microwave-assisted reactions were performed in a CEM Discover microwave oven.

\section{2-Aminobenzaldehyde (15) ${ }^{17 c}$}

2-Nitrobenzaldehyde (13, $500 \mathrm{mg}, 3.3 \mathrm{mmol})$ was added to a refluxing mixture of clean iron powder $(1020 \mathrm{mg}, 18.3 \mathrm{mmol})$ and $\mathrm{NH}_{4} \mathrm{Cl}(120 \mathrm{mg}, 2.2 \mathrm{mmol})$ in $\mathrm{EtOH}: \mathrm{H}_{2} \mathrm{O}(9: 1, \mathrm{v} / \mathrm{v}, 50 \mathrm{~mL})$. The reaction mixture was stirred at reflux for $2 \mathrm{~h}$ under an argon atmosphere; then it was allowed to cool to room temperature, filtered and the residue was washed with EtOH. The filtrate was concentrated under reduced pressure and the resulting oily residue was redissolved in EtOAc $(50 \mathrm{~mL})$ and washed with saturated $\mathrm{NaHCO}_{3}$ solution ( $5 \mathrm{~mL}$ ). The organic layer was dried $\left(\mathrm{MgSO}_{4}\right)$ and concentrated to afford 15 (385 mg, 96\%), as a stinky yellow oil, which slowly crystallized on standing to give a solid with a low melting point. IR (film, $\nu$ ): 3459, 3443, 3418, 3333, 3321, 3282, 3100, 2916, 2848, 2700, 2357, 1643, 1591, 1557, 1479, 1454, 1396, 1317, 1205, 1155, 1026, 883, 748, 665 and $627 \mathrm{~cm}^{-1}$. ${ }^{1} \mathrm{H}$ NMR: $\delta 6.11\left(\mathrm{br} \mathrm{s}, w_{1 / 2}=29.2,2 \mathrm{H}, \mathrm{NH}_{2}\right), 6.64$ $(\mathrm{d}, 1 \mathrm{H}, J=8.4, \mathrm{H}-3), 6.75$ (ddd, $J=7.8,7.2$ and 1.0, 1H, H-5), 7.31 (ddd, $J=8.4,7.2$ and 1.6, $1 \mathrm{H}, \mathrm{H}-4), 7.48(\mathrm{dd}, J=7.8$ and 1.6, $1 \mathrm{H}$, $\mathrm{H}-6)$ and 9.87 (s, 1H, CHO). ${ }^{13} \mathrm{C}$ NMR: $\delta 116.0$ (C-3), 116.3 (C-5), 118.8 (C-1), 135.2 (C-4), 135.7 (C-6), 149.9 (C-2) and 194.0 (CHO).

\section{$\mathrm{N}$-(2-Formylphenyl)-2-(2-nitrophenyl)acetamide (16)}

A solution of 2-nitrophenylacetic acid $(12,561 \mathrm{mg}, 3.1 \mathrm{mmol})$, pyridine $(0.67 \mathrm{~mL}, 8.36 \mathrm{mmol})$ and DMF $(0.071 \mathrm{~mL}, 0.93 \mathrm{mmol})$ in $\mathrm{PhCF}_{3}(20 \mathrm{~mL})$ was stirred $1 \mathrm{~h}$ at room temperature. Then, a solution of 2-aminobenzaldehyde $(376 \mathrm{mg}, 3.1 \mathrm{mmol})$ in $\mathrm{PhCF}_{3}(10 \mathrm{~mL})$ was added to the mixture, which was successively treated dropwise at $0{ }^{\circ} \mathrm{C}$ with $\mathrm{POCl}_{3}(0.20 \mathrm{~mL}, 2.17 \mathrm{mmol})$. The mixture was stirred $3 \mathrm{~h}$ at room temperature, most of the solvent was recovered under reduced pressure, saturated $\mathrm{Na}_{2} \mathrm{CO}_{3}(10$ $\mathrm{mL}$ ) was added, and the mixture was stirred for additional $30 \mathrm{~min}$. The organic products were extracted with EtOAc $(4 \times 15$ $\mathrm{mL}$ ), and the combined organic phases were washed with brine (10 $\mathrm{mL})$, dried $\left(\mathrm{MgSO}_{4}\right)$, and concentrated under reduced pressure. Chromatography of the residue furnished 16 (854 mg, 97\%) as a yellow solid, mp 142-144 ${ }^{\circ} \mathrm{C}$. IR (KBr, $\left.\nu\right): 3285,3100$, 3050, 2930, 2850, 2700, 1813, 1740, 1607, 1490, 1450, 1369, 1240, 1215, 1059, 1043, 1030, 968, 885, 835, 797, 758 and 698 $\mathrm{cm}^{-1} .{ }^{1} \mathrm{H}$ NMR: $\delta 4.18\left(\mathrm{~s}, 2 \mathrm{H}, \mathrm{NHCOCH}_{2}\right), 7.22(\mathrm{dt}, J=7.5$ and $0.9,1 \mathrm{H}, \mathrm{H}-4), 7.49\left(\mathrm{dd}, J=7.6\right.$ and $\left.1.4,1 \mathrm{H}, \mathrm{H}-6^{\prime}\right), 7.54(\mathrm{dt}, J=7.8$ and 1.7, $\left.1 \mathrm{H}, \mathrm{H}-4^{\prime}\right), 7.57(\mathrm{dt}, J=7.8$ and $1.8,1 \mathrm{H}, \mathrm{H}-5), 7.65(\mathrm{dd}, J$ $=7.6$ and $1.7,1 \mathrm{H}, \mathrm{H}-3), 7.67\left(\mathrm{dt}, J=7.6\right.$ and $\left.1.4,1 \mathrm{H}, \mathrm{H}-5^{\prime}\right), 8.17$ $(\mathrm{dd}, J=8.1$ and 1.2, 1H, H-3'), 8.69 (d, $J=8.4,1 \mathrm{H}, \mathrm{H}-6), 9.85$ (s, 
$1 \mathrm{H}, \mathrm{CHO}$ ) and 11.21 (br s, $\left.w_{1 / 2}=9.3,1 \mathrm{H}, \mathrm{NHCOCH}{ }_{2}\right) .{ }^{13} \mathrm{C} \mathrm{NMR}$ : $\delta 43.1\left(\mathrm{NHCOCH}_{2}\right), 120.0$ (C-6), 121.7 (C-2), 123.1 (C-4), 125.5 (C3'), 128.9 (C-4'), 129.5 (C-1'), $133.8\left(\mathrm{C}-5^{\prime}\right), 133.8\left(\mathrm{C}-6^{\prime}\right), 135.9(\mathrm{C}-$ 3), 136.2 (C-5), 140.7 (C-1), $149.0\left(\mathrm{C}-2^{\prime}\right), 168.5\left(\mathrm{NHCOCH}_{2}\right)$ and $195.5(\mathrm{COH})$. HRMS $\mathrm{m} / z$ calcd for $\mathrm{C}_{15} \mathrm{H}_{13} \mathrm{~N}_{2} \mathrm{O}_{4} 285.0870[\mathrm{M}+$ $\mathrm{H}]^{+}$; found: 285.0861 .

\section{3-(2-Nitrophenyl)quinolin-2(1H)-one (11)}

A stirred solution of carboxamidobenzaldehyde 16 (197 mg, $0.69 \mathrm{mmol}$ ) in anhydrous DMF $(7 \mathrm{~mL})$ was treated with $\mathrm{K}_{2} \mathrm{CO}_{3}$ (447 $\mathrm{mg}, 3.45 \mathrm{mmol}$ ) and the reaction mixture was heated at $100{ }^{\circ} \mathrm{C}$ for $1 \mathrm{~h}$ under an argon atmosphere. Once warmed to room temperature, the reaction mixture was diluted with EtOAc $(50 \mathrm{~mL})$ and successively washed with a saturated solution of $\mathrm{NH}_{4} \mathrm{Cl}(10 \mathrm{~mL})$ and water $(10 \mathrm{~mL})$. The organic phase was concentrated in vacuo to give 11 (184 mg, 99\%), as an orangebrown solid, mp 320-321 ${ }^{\circ} \mathrm{C}$ (lit.: $\left.317-318{ }^{\circ} \mathrm{C}\right) .{ }^{20 a}$ IR $(\mathrm{KBr}, \nu)$ : 3220, 2922, 2891, 2851, 1653, 1609, 1564, 1560, 1522, 1431, 1356, 1233, 1150, 955, 928, 785, 754, 710 and $631 \mathrm{~cm}^{-1} \cdot{ }^{1} \mathrm{H}$ NMR (DMSO- $\left.d_{6}\right): \delta 7.24(\mathrm{t}, J=7.6,1 \mathrm{H}, \mathrm{H}-6), 7.35(\mathrm{~d}, J=8.2,1 \mathrm{H}, \mathrm{H}-8)$, $7.55(\mathrm{t}, J=8.2,1 \mathrm{H}, \mathrm{H}-7), 7.64\left(\mathrm{dd}, J=7.3\right.$ and $\left.1.5,1 \mathrm{H}, \mathrm{H}-6^{\prime}\right), 7.67$ $\left(\mathrm{dt}, J=8.0\right.$ and $\left.1.5,1 \mathrm{H}, \mathrm{H}-4^{\prime}\right), 7.76(\mathrm{~d}, J=7.6,1 \mathrm{H}, \mathrm{H}-5), 7.82(\mathrm{t}, J$ $\left.=7.3,1 \mathrm{H}, \mathrm{H}-5^{\prime}\right), 8.04\left(\mathrm{~d}, J=8.0,1 \mathrm{H}, \mathrm{H}-3^{\prime}\right), 8.15(\mathrm{~s}, 1 \mathrm{H}, \mathrm{H}-4)$ and $11.97(\mathrm{~s}, 1 \mathrm{H}, \mathrm{NH}) .{ }^{13} \mathrm{C}$ NMR (DMSO- $\left.d_{6}\right): \delta 115.5$ (C-8), $119.9(\mathrm{C}-$ 4a), 122.7 (C-6), 124.4 (C-3'), 128.8 (C-5), 129.9 (C-4'), 131.2 (C7), 131.4 (C-3), ${ }^{*} 131.5\left(\mathrm{C}-1^{\prime}\right),{ }^{*} 132.7\left(\mathrm{C}-6^{\prime}\right), 134.2\left(\mathrm{C}-5^{\prime}\right), 138.1$ (C-4), 139.0 (C-8a), $149.4\left(\mathrm{C}-2^{\prime}\right)$ and 160.5 (C-2). HRMS $\mathrm{m} / \mathrm{z}$ calcd for $\mathrm{C}_{15} \mathrm{H}_{11} \mathrm{~N}_{2} \mathrm{O}_{3} 267.0764[\mathrm{M}+\mathrm{H}]^{+}$; found: 267.0768 .

\section{Pyridine hydrochloride $(\mathrm{Py} \cdot \mathrm{HCl})$}

Concentrated $\mathrm{HCl}(5.12 \mathrm{~mL})$ was added dropwise to a vigorously stirred solution of pyridine $(5 \mathrm{~mL})$ in $\mathrm{Et}_{2} \mathrm{O}(30 \mathrm{~mL})$ at room temperature. A white precipitate was immediately formed. The slurry thus obtained was filtered and the solid product was washed with $\mathrm{Et}_{2} \mathrm{O}$, recrystallized from $\mathrm{CHCl}_{3} / \mathrm{EtOAc}$ and further washed with $\mathrm{Et}_{2} \mathrm{O}$. The resulting purified material was dried under vacuum and stored into a desiccator.

\section{H-Indolo[2,3-b]quinoline (quinindoline, 8$)^{5 a}$}

Method A. Iron powder (70 $\mathrm{mg}, 0.26 \mathrm{mmol}$ ) was added to a solution of 11 (121 mg, $2.16 \mathrm{mmol})$ in glacial AcOH $(2 \mathrm{~mL})$ at $110^{\circ} \mathrm{C}$ under an argon atmosphere. After stirring overnight at $110^{\circ} \mathrm{C}$, the solids were removed by filtration and the filtrate was concentrated under reduced pressure. The residue was chromatographed to give 3-(2-acetamidophenyl)quinolin-2(1H)-one $(\mathbf{1 7}, 141 \mathrm{mg}, 99 \%)$ as a brown solid, $\mathrm{mp} 236-238{ }^{\circ} \mathrm{C}$; IR $(\mathrm{KBr}, \nu)$ : 3300, 3050, 2953, 2918, 2893, 2851, 2300, 1700, 1670, 1637, 1582, 1541, 1449, 1429, 1369, 1312, 1200, 737, 592 and 569 $\mathrm{cm}^{-1} .{ }^{1} \mathrm{H}$ NMR: $\delta 2.04(\mathrm{~s}, 3 \mathrm{H}, \mathrm{COMe}), 7.27\left(\mathrm{t}, J=7.4,1 \mathrm{H}, \mathrm{H}-5^{\prime}\right)$, 7.32 (dd, $J=8.0$ and $7.7,1 \mathrm{H}, \mathrm{H}-6), 7.36$ (dd, $J=7.4$ and $1.5,1 \mathrm{H}$, H-6 ${ }^{\prime}$ ), 7.40 (d, $\left.J=8.3,1 \mathrm{H}, \mathrm{H}-8\right), 7.48$ (ddd, $J=8.2,7.4$ and 1.5, $\left.1 \mathrm{H}, \mathrm{H}-4^{\prime}\right), 7.58(\mathrm{dt}, J=7.7$ and $1.3,1 \mathrm{H}, \mathrm{H}-7), 7.68(\mathrm{~d}, J=8.0,1 \mathrm{H}$, $\mathrm{H}-5$ ), 7.90 (d, $J=8.2,1 \mathrm{H}, \mathrm{H}-3^{\prime}$ ), 7.98 (s, 1H, H-4), 9.20 (br s, $1 \mathrm{H}$, NHCOMe), 11.73 (br s, $1 \mathrm{H}, \mathrm{H}-1) .{ }^{13} \mathrm{C}$ NMR: $\delta 24.4$ (COMe), 115.5 (C-8), 120.3 (C-4a), 123.7 (C-6), 125.5 (C-3' and C-5'), 128.4 (C-5), $129.3\left(\mathrm{C}-4^{\prime}\right), 130.0\left(\mathrm{C}-1^{\prime}\right), 131.3(\mathrm{C}-7$ and C-6'), 131.8 (C-3), 136.6
(C-2'), 137.7 (C-8a), 142.8 (C-4), 163.2 (C-2), 170.0 (COMe). Without further purification, compound 17 (100 mg, 0.36 $\mathrm{mmol})$ and anhydrous $\mathrm{Py} \cdot \mathrm{HCl}(1.0 \mathrm{~g})$ were successively transferred to a reaction vessel, which in turn was placed in a preheated sand bath at $240{ }^{\circ} \mathrm{C}$ for $10 \mathrm{~min}$. Then, the heating bath was removed and when the system reached room temperature, $\mathrm{H}_{2} \mathrm{O}$ was added $(10 \mathrm{~mL})$ to dissolve the brownish cake, affording a suspension that was filtered under reduced pressure. The residue was washed with $\mathrm{H}_{2} \mathrm{O}$ and dried to afford the tetracycle 8 (55 mg, 70\%), as a yellow solid, mp $298-299{ }^{\circ} \mathrm{C}$ (lit.: $\left.>300{ }^{\circ} \mathrm{C}\right) .{ }^{10 c} \mathrm{IR}(\mathrm{KBr}, \nu): 2918,2849,1645,1500,1454,1260$, 1100 and $1011 \mathrm{~cm}^{-1} .{ }^{1} \mathrm{H}$ NMR (DMSO- $\left.d_{6}\right): \delta 7.26$ (ddd, $J=8.1$, 7.7 and 2.1, $1 \mathrm{H}, \mathrm{H}-9), 7.45-7.53(\mathrm{~m}, 3 \mathrm{H}, \mathrm{H}-2, \mathrm{H}-7$ and $\mathrm{H}-8), 7.73$ (ddd, $J=8.5,6.7$ and 1.4, 1H, H-3), 7.97 (d, $J=8.5,1 \mathrm{H}, \mathrm{H}-4), 8.10$ (d, $J=7.6,1 \mathrm{H}, \mathrm{H}-1), 8.25$ (d, $J=7.7,1 \mathrm{H}, \mathrm{H}-10), 9.05$ (s, 1H, H-11) and 11.72 (br s, $\left.w_{1 / 2}=8.8,1 \mathrm{H}, \mathrm{H}-6\right) .{ }^{13} \mathrm{C}$ NMR (DMSO- $d_{6}$ ): $\delta 111.4$ (C-7), 118.4 (C-10b), 120.2 (C-9), 120.5 (C-10a), 122.1 (C10), 123.3 (C-2), 123.9 (C-11a), 126.8 (C-4), 128.3 (C-11), 128.7 (C8), 129.0 (C-1), 129.3 (C-3), 141.7 (C-6a), 146.0 (C-4a) and 152.8 (C-5a). The spectroscopic data of the synthetic compound were in full agreement with those of the literature.

Method B. Compound 11 (50 mg, $0.19 \mathrm{mmol}$ ) was added to a refluxing mixture of clean iron powder $(58 \mathrm{mg}, 1.04 \mathrm{mmol})$ and $\mathrm{NH}_{4} \mathrm{Cl}(7 \mathrm{mg}, 0.13 \mathrm{mmol})$ in EtOH : $\mathrm{H}_{2} \mathrm{O}(10: 1 \mathrm{v} / \mathrm{v}, 3 \mathrm{~mL})$ and the reaction mixture was stirred at reflux for $2 \mathrm{~h}$ under an argon atmosphere. Then, the solids were removed by filtration and the filtrate was concentrated under reduced pressure. The residue was redissolved in EtOAc $(40 \mathrm{~mL})$ and washed with saturated $\mathrm{NaHCO}_{3}$ solution $(2 \times 4 \mathrm{~mL})$. The organic layer was dried $\left(\mathrm{MgSO}_{4}\right)$ and concentrated in vacuo to afford $18(44 \mathrm{mg}$, $99 \%$ ) as an orange-brown solid. Mp 224-226 ${ }^{\circ} \mathrm{C}$. IR ( $\left.\mathrm{KBr}, \nu\right)$ : 3100, 2953, 2918, 2849, 2359, 2150, 1715, 1607, 1574, 1495, 1471, 1429, 1396, 1321, 1258, 1119, 1050, 850, 787 and 743 $\mathrm{cm}^{-1} .{ }^{1} \mathrm{H}$ NMR: $\delta 4.26\left(\mathrm{br} \mathrm{s}, w_{1 / 2}=31.9,2 \mathrm{H}, \mathrm{N} H_{2}\right), 6.82(\mathrm{dd}, J=$ 8.1 and $\left.1.3,1 \mathrm{H}, \mathrm{H}-3^{\prime}\right), 6.88\left(\mathrm{dt}, J=7.2\right.$ and $\left.1.3,1 \mathrm{H}, \mathrm{H}-5^{\prime}\right), 7.20-$ $7.30\left(\mathrm{~m}, 3 \mathrm{H}, \mathrm{H}-4^{\prime}, \mathrm{H}-6^{\prime}\right.$ and $\left.\mathrm{H}-6\right), 7.32(\mathrm{~d}, J=8.3,1 \mathrm{H}, \mathrm{H}-8), 7.48$ $(\mathrm{dt}, J=7.5$ and $1.2,1 \mathrm{H}, \mathrm{H}-7), 7.61(\mathrm{dd}, J=7.8$ and $1.2,1 \mathrm{H}, \mathrm{H}-5)$, $7.91(\mathrm{~s}, 1 \mathrm{H}, \mathrm{H}-4)$ and $11.68\left(\mathrm{br} \mathrm{s}, w_{1 / 2}=21.6,1 \mathrm{H}, \mathrm{NH}\right) .{ }^{13} \mathrm{C} \mathrm{NMR}$ $\delta 115.6(\mathrm{C}-8), 117.2\left(\mathrm{C}-3^{\prime}\right),{ }^{*} 119.1\left(\mathrm{C}-5^{\prime}\right),{ }^{*} 120.3(\mathrm{C}-5 \mathrm{a}), 123.0(\mathrm{C}-$ 6), $123.8\left(\mathrm{C}-1^{\prime}\right), 127.9(\mathrm{C}-5), 129.5\left(\mathrm{C}-4^{\prime}\right), 130.5$ (C-7), $131.4\left(\mathrm{C}-6^{\prime}\right)$, 132.7 (C-3), 137.8 (C-8a), 141.4 (C-4), 145.9 (C-2') and $162.6(\mathrm{C}-2)$. Without further purification, the cyclization procedure of Method A was applied on 18 (14 mg, $0.06 \mathrm{mmol})$, employing anhydrous $\mathrm{Py} \cdot \mathrm{HCl}(1.0 \mathrm{~g})$. This afforded the tetracycle 8 $(12.0 \mathrm{mg}, 93 \%)$, as a yellow solid. Alternatively, $\mathrm{POCl}_{3}(0.046 \mathrm{~mL}$, $0.49 \mathrm{mmol}$ ) was added dropwise to a stirred solution of 18 (38 $\mathrm{mg}, 0.16 \mathrm{mmol})$ in $\mathrm{MeCN}(2.2 \mathrm{~mL})$ at $0{ }^{\circ} \mathrm{C}$, the tube was sealed and the mixture was heated overnight at $90{ }^{\circ} \mathrm{C}$. After evaporation of the solvent and the $\mathrm{POCl}_{3}$, the residue was treated with a solution of DIPEA $(0.175 \mathrm{~mL}, 1.00 \mathrm{mmol})$ in $\operatorname{MeCN}(3 \mathrm{~mL})$ and the reaction was heated overnight at $120{ }^{\circ} \mathrm{C}$ in a sealed tube. After evaporation of the solvent and the DIPEA, the residue was chromatographed to give 8 (33 $\mathrm{mg}, 94 \%$ ), as a yellow solid. In both cases, the spectroscopic data of the product were in full agreement with those of the solid obtained employing Method A and with the literature. 
6-Methyl-6H-indolo[2,3-b]quinoline (6-methylquinindoline, 10) ${ }^{10 b}$

A mixture of 8 (10 mg, $0.046 \mathrm{mmol})$, DMC ( $15 \mu \mathrm{L}, 0.18 \mathrm{mmol})$, calcined $\mathrm{MgO}(7 \mathrm{mg}, 0.18 \mathrm{mmol})$ and anhydrous DMF $(1 \mathrm{~mL})$ was poured in a sealed reaction vessel and heated in a microwave reactor at $170{ }^{\circ} \mathrm{C}$ for 30 minutes. The slurry was cooled to room temperature, the solids filtered off and washed with EtOAc $(3 \times 10 \mathrm{~mL})$. The organic phase was washed with $\mathrm{H}_{2} \mathrm{O}(5$ $\mathrm{mL})$, dried $\left(\mathrm{MgSO}_{4}\right)$ and concentrated under reduced pressure to afford $10(9.5 \mathrm{mg}, 89 \%)$, as an orange-brown solid, $\mathrm{mp} \mathrm{78-}$ $81^{\circ} \mathrm{C}$ (lit.: $\left.83-87^{\circ} \mathrm{C}\right) .{ }^{14 d} \mathrm{IR}(\mathrm{KBr}, \nu): 3050,2953,2918,2849,2358$, 2305, 2150, 1714, 1607, 1574, 1495, 1472, 1430, 1396, 1321, 1258, 1119, 1010, 786 and $743 \mathrm{~cm}^{-1} .{ }^{1} \mathrm{H}$ NMR: $\delta 4.01(\mathrm{~s}, 3 \mathrm{H}, \mathrm{N}-$ $\left.\mathrm{CH}_{3}\right), 7.32$ (ddd, $J=7.7,7.4$ and $\left.0.9,1 \mathrm{H}, \mathrm{H}-9\right), 7.40-7.50(\mathrm{~m}, 2 \mathrm{H}$, $\mathrm{H}-2$ and $\mathrm{H}-7$ ), 7.60 (ddd, $J=7.5,7.3$ and $1.2,1 \mathrm{H}, \mathrm{H}-8$ ), 7.72 (ddd, $J=8.5,6.7$ and $1.4,1 \mathrm{H}, \mathrm{H}-3), 8.02(\mathrm{dd}, J=8.1$ and $1.3,1 \mathrm{H}, \mathrm{H}-1)$, $8.14(\mathrm{~d}, J=8.5,1 \mathrm{H}, \mathrm{H}-10), 8.17(\mathrm{~d}, J=7.9,1 \mathrm{H}, \mathrm{H}-4)$ and $8.73(\mathrm{~s}$, 1H, H-11). ${ }^{13} \mathrm{C}$ NMR: $\delta 27.8$ (N-Me), 108.7 (C-7), 118.3 (C-10b), 120.0 (C-9), 120.4 (C-10a), 121.4 (C-4), 122.9 (C-2), 124.1 (C11a), 127.4 (C-10 and C-11), 128.1 (C-8), 128.5 (C-1), 128.9 (C3), 142.9 (C-6a), 146.8 (C-4a) and 152.8 (C-5a).

\section{1-Methyl-3-(2-nitrophenyl)quinolin-2(1H)-one (14) ${ }^{12 h}$}

A solution of $11(130 \mathrm{mg}, 0.48 \mathrm{mmol}), \mathrm{DBU}(7.2 \mu \mathrm{L}, 0.048 \mathrm{mmol})$ and DMF ( $68 \mu \mathrm{L}, 0.88 \mathrm{mmol})$ in DMC $(0.68 \mathrm{~mL}, 8.1 \mathrm{mmol})$ was stirred overnight at $90^{\circ} \mathrm{C}$. After evaporation of the volatiles, the residue was chromatographed to give $\mathbf{1 4}(130 \mathrm{mg}, 95 \%)$, as an amber solid, mp 141-143 ${ }^{\circ} \mathrm{C}$. IR ( $\left.\mathrm{KBr}, \nu\right): 3250,3063,2957,2917$, 2849, 2359, 2342, 2330, 1648, 1593, 1526, 1454, 1354, 1238, 1121, 1040, 945, 860, 789, 754 and $721 \mathrm{~cm}^{-1} .{ }^{1} \mathrm{H}$ NMR: $\delta 3.75$ (s, $3 \mathrm{H}, \mathrm{N}-\mathrm{Me}), 7.29$ (dt, $J=7.5$ and 1.0, 1H, H-6), 7.40 (d, $J=8.4$, $1 \mathrm{H}, \mathrm{H}-8), 7.46$ (dd, $J=7.7$ and $1.5,1 \mathrm{H}, \mathrm{H}-5), 7.54(\mathrm{dt}, J=7.9$ and 1.4, $1 \mathrm{H}, \mathrm{H}-4^{\prime}$ ), 7.60-7.70 (m, 3H, H-5', H-6', H-7), 7.40 (d, $J=8.4$, $1 \mathrm{H}, \mathrm{H}-8), 7.81(\mathrm{~s}, 1 \mathrm{H}, \mathrm{H}-4)$ and $8.07(\mathrm{dd}, J=8.1$ and $1.3,1 \mathrm{H}, \mathrm{H}-$ $\left.3^{\prime}\right) .{ }^{13} \mathrm{C}$ NMR: $\delta 30.0$ (N-Me), 114.3 (C-8), 120.5 (C-4a), 122.4 (C-6), 124.9 (C-3'), 129.0 (C-6'), 129.1 (C-4'), 130.9 (C-7), 131.5 (C-1'), * 131.9 (C-5), 132.0 (C-3), 133.1 (C-5'), * 136.4 (C-4), 140.0 (C-8a), $149.5\left(\mathrm{C}-2^{\prime}\right)$ and $160.5(\mathrm{C}=\mathrm{O})$.

\section{3-(2-Aminophenyl)-1-methylquinolin-2(1H)-one (19) ${ }^{12 g, h}$}

A stirred solution of $\mathbf{1 4}(120 \mathrm{mg}, 0.45 \mathrm{mmol})$ in EtOH : $\mathrm{H}_{2} \mathrm{O}$ $(10: 1 \mathrm{v} / \mathrm{v}, 8 \mathrm{~mL})$ was treated with $\mathrm{NH}_{4} \mathrm{Cl}(16.8 \mathrm{mg}, 0.315 \mathrm{mmol})$ and iron powder $(138.6 \mathrm{mg}, 2.48 \mathrm{mmol})$. The mixture was heated to reflux for $3 \mathrm{~h}$, when it was allowed to cool to room temperature and filtered. The filtrate was diluted with brine (10 $\mathrm{mL})$ and organic products were extracted with EtOAc $(4 \times 10$ $\mathrm{mL}$ ). The combined organic phases were washed with brine (10 $\mathrm{mL})$, dried $\left(\mathrm{MgSO}_{4}\right)$, and concentrated under reduced pressure. The residue was passed through a short plug of silica gel, affording 19 (102 mg, 96\%), as a solid, $\mathrm{mp} 163-165{ }^{\circ} \mathrm{C}$ (lit.: $172-$ $\left.174{ }^{\circ} \mathrm{C}\right) .{ }^{11 b}$ IR (KBr, film): 3416, 3335, 3223, 2916, 2849, 2361, 2328, 1643, 1584, 1568, 1557, 1495, 1454, 1304, 1236, 1038, 945, 789, 750 and $656 \mathrm{~cm}^{-1} .{ }^{1} \mathrm{H}$ NMR: $\delta 3.82(\mathrm{~s}, 3 \mathrm{H}, \mathrm{N}-\mathrm{Me}), 4.18(\mathrm{br} \mathrm{s}$, $\left.2 \mathrm{H}, \mathrm{NH}_{2}\right), 6.79$ (d, $\left.J=7.7,1 \mathrm{H}, \mathrm{H}-3^{\prime}\right), 6.85\left(\mathrm{dt}, J=7.7,1 \mathrm{H}, \mathrm{H}-4^{\prime}\right)$, 7.15-7.21 (m, 1H, H-5'), 7.22 (dd, $J=7.4$ and 1.2, $\left.1 \mathrm{H}, \mathrm{H}-6^{\prime}\right), 7.28$ (dt, $J=7.5$ and $0.8,1 \mathrm{H}, \mathrm{H}-6), 7.41(\mathrm{~d}, J=8.5,1 \mathrm{H}, \mathrm{H}-8), 7.55-7.65$ (m, $1 \mathrm{H}, \mathrm{H}-7), 7.61(\mathrm{~d}, J=7.5,1 \mathrm{H}, \mathrm{H}-5)$ and $7.80(\mathrm{~s}, 1 \mathrm{H}, \mathrm{H}-4) .{ }^{13} \mathrm{C}$ NMR: $\delta 30.1$ (N-Me), 114.1 (C-8), 117.2 (C-3'), $119.0\left(\mathrm{C}-4^{\prime}\right), 120.7$ (C-4a), 122.5 (C-6), 124.5 (C-3), 129.0 (C-5), 129.4 (C-6'), 130.5 (C7), $131.2\left(\mathrm{C}-5^{\prime}\right), 132.6$ (C-1'), 139.5 (C-4), 139.5 (C-8a), $145.8\left(\mathrm{C}-2^{\prime}\right)$ and $161.2(\mathrm{C}=\mathrm{O})$.

\section{Neocryptolepine (1)}

$\mathrm{POCl}_{3}(0.1 \mathrm{~mL}, 1.08 \mathrm{mmol})$ was added dropwise to a stirred solution of $19(85 \mathrm{mg}, 0.36 \mathrm{mmol})$ in $\mathrm{MeCN}(4 \mathrm{~mL})$ at $0{ }^{\circ} \mathrm{C}$, the tube was sealed and the mixture was heated overnight at $90^{\circ} \mathrm{C}$. After evaporation of the solvent and the $\mathrm{POCl}_{3}$, the residue was treated with a solution of DIPEA $(0.35 \mathrm{~mL}, 6.48 \mathrm{mmol})$ in MeCN $(4 \mathrm{~mL})$ and the reaction was heated overnight at $120{ }^{\circ} \mathrm{C}$ in a sealed tube. After evaporation of the solvent and the DIPEA, the residue was chromatographed to give $1(50 \mathrm{mg}, 63 \%)$, as a deep orange solid, mp $104-106^{\circ} \mathrm{C}$ (lit.: $\left.104-106^{\circ} \mathrm{C}\right){ }^{8 b} \mathrm{IR}(\mathrm{KBr}$, v): 3528, 3462, 3422, 3404, 3383, 3366, 2918, 2800, 2400, 1951, 1750, 1647, 1558, 1419, 1203, 1101, 1061 and $746 \mathrm{~cm}^{-1} \cdot{ }^{1} \mathrm{H}$ NMR: $\delta 4.37$ (s, 3H, N-Me), $7.24(\mathrm{ddd}, J=7.6,7.4$ and $1.1,1 \mathrm{H}, \mathrm{H}-$ 9), 7.42-7.48 (m, 1H, H-2), 7.55 (ddd, $J=7.4,7.2$ and $1.2,1 \mathrm{H}, \mathrm{H}-$ 8), 7.73-7.79 (m, 3H, H-3, H-4 and H-7), 8.00 (d, $J=7.9,1 \mathrm{H}, \mathrm{H}-1)$, $8.05(\mathrm{~d}, J=7.6,1 \mathrm{H}, \mathrm{H}-10)$ and $8.54(\mathrm{~s}, 1 \mathrm{H}, \mathrm{H}-11) .{ }^{13} \mathrm{C}$ NMR: $\delta 33.3$ (N-Me), 114.1 (C-4), 117.7 (C-7), 119.9.4 (C-9), 120.8 (C-11a), 121.0 (C-10), 121.9 (C-2), 124.0 (C-10a), 128.1 (C-11), 128.2 (C10b), 129.3 (C-8), 130.0 (C-1), 130.4 (C-3), 137.0 (C-4a) and 155.4 (C-6a). The spectroscopic data of the synthetic compound were in full agreement with those of the literature.

\section{Acknowledgements}

The authors gratefully acknowledge Secretaría de Ciencia y Tecnología de la UNR (SECyT-UNR), Consejo Nacional de Investigaciones Científicas y Técnicas (CONICET), and Agencia Nacional de Promoción Científica y Tecnológica (ANPCyT), Projects BIO457, PIP No. 2012-0471 and PICT No. 2011-0455, respectively, for financial support. M. V. M. and D. A. H. also thank CONICET for their fellowships.

\section{Notes and references}

1 (a) A. A. Appiah, The Golden Roots of Cryptolepis sanguinolenta, in Chemistry and Quality - African Natural Plant Products: New Discoveries and Challenges, ACS, Washington, D.C., 2009, ch. 13, pp. 231-239; (b) F. R. Irvine, in Woody Plants of Ghana, Oxford University Press, London, 1961; (c) P. T. Parvatkar and S. G. Tilve, Bioactivities and synthesis of indoloquinoline alkaloids: cryptolepine, isocryptolepine and neocryptolepine, in Bioactive Heterocycles: Synthesis and Biological Evaluation, ed. K. L. Ameta, R. P. Pawar and A. J. Domb, Nova Science Publishers, 2012, ch. 10, pp. 218-233.

2 (a) P. T. Parvatkar, P. S. Parameswaran and S. G. Tilve, Curr. Org. Chem., 011, 15, 1036-1057; (b) J. Lavrado, R. Moreira and A. Paul, Curr. Med. Chem., 2010, 17, 2348-2370; (c) L. R. Whittell, K. T. Batty, R. P. M. Wong, E. M. Bolitho, 
S. A. Fox, T. M. E. Davis and P. E. Murray, Bioorg. Med. Chem., 2011, 19, 7519-7525; (d) J. Lavrado, G. G. Cabal, M. Prudêncio, M. M. Mota, J. Gut, P. J. Rosenthal, C. Díaz, R. C. Guedes, D. J. V. A. dos Santos, E. Bichenkova, K. T. Douglas, R. Moreira and A. Paulo, J. Med. Chem., 2011, 54, 734-750.

3 (a) M. H. M. Sharaf, P. L. Schiff Jr, A. N. Tackie, C. H. Phoebe Jr and G. E. Martin, J. Heterocycl. Chem., 1996, 33, 239-243; (b) S. D. Ablordeppey, C. D. Hufford, R. F. Borne and D. Dwama-Badu, Planta Med., 1990, 56, 416-417; (c) A. N. Tackie, M. H. M. Sharaf, P. L. Schiff Jr, G. L. Boye, R. C. Crouch and G. E. Martin, J. Heterocycl. Chem., 1991, 28, 1429-1435; (d) D. Dwuma-Badu, J. S. K. Ayim, N. Y. Y. Fiagbe, J. E. Knapp, P. L. Schiff Jr and D. J. Slatkin, J. Pharm. Sci., 1978, 67, 433-434; (e) R. C. Crouch, A. O. Davis, T. D. Spitzer, G. E. Martin, M. H. M. Sharaf, P. L. Schiff Jr, C. H. Phoebe and A. N. Tackie, J. Heterocycl. Chem., 1995, 32, 1077-1080.

4 (a) J.-L. Pousset, M.-T. Martin, A. Jossang and B. Bodo, Phytochemistry, 1995, 39, 735-736; (b) C. E. Hadden, M. H. M. Sharaf, J. E. Guido, R. H. Robins, A. N. Tackie, C. H. Phoebe Jr, P. L. Schiff Jr and G. E. Martin, J. Nat. Prod., 1999, 62, 238-240; (c) D. M. Fort, J. Litvak, J. L. Chen, Q. Lu, P. W. Phuan, R. Cooper and D. E. Bierer, J. Nat. Prod., 1998, 61, 1528-1530; (d) A. Paulo, E. T. Gomes and P. J. Houghton, J. Nat. Prod., 1995, 58, 1485-1491.

5 (a) G. V. Subbaraju, J. Kavitha, D. Rajasekhar and J. I. Jimenez, J. Nat. Prod., 2004, 67, 461-462; (b) K. Cimanga, T. De Bruyne, L. Pieters, M. Claeys and A. Vlietnick, Tetrahedron Lett., 1996, 37, 1703-1706.

6 (a) M. H. M. Sharaf, P. L. Schiff Jr, A. N. Tackie, C. H. Phoebe Jr, L. Howard, C. Myers, C. E. Hadden, S. K. Wrenn, A. O. Davis, C. W. Andrews, D. Minick, R. L. Johnson, J. P. Shockcor, R. C. Crouch and G. E. Martin, Magn. Reson. Chem., 1995, 33, 767-778; (b) A. N. Tackie, G. L. Boye, M. H. M. Sharaf, P. L. Schiff Jr, R. C. Crouch, T. D. Spitzer, R. L. Johnson, J. Dunn, D. Minick and G. E. Martin, J. Nat. Prod., 1993, 56, 653-670; (c) K. Blinov, M. Elyashberg, E. R. Martirosian, S. G. Molodtsov, A. J. Williams, A. N. Tackie, M. H. M. Sharaf, P. L. Schiff Jr, R. C. Crouch, G. E. Martin, C. E. Hadden, J. E. Guido and K. A. Mills, Magn. Reson. Chem., 2003, 41, 577-584; (d) M. H. M. Sharaf, P. L. Schiff Jr, A. N. Tackie, C. H. Phoebe Jr, R. L. Johnson, D. Minick, C. W. Andrews, R. C. Crouch and G. E. Martin, J. Heterocycl. Chem., 1996, 33, 789-797.

7 (a) F. Ahmed, K. Toume, T. Ohtsuki, M. Rahman, S. K. Sadhu and M. Ishibashi, Phytother. Res., 2011, 25, 147-150; (b) S. W. Yang, M. Abdel-Kader, S. Malone, M. C. M. Werkhoven, J. H. Wisse, I. Bursuker, K. Neddermann, C. Fairchild, C. Raventos-Suárez, A. T. Menendez, K. Lane and D. G. I. Kingston, J. Nat. Prod., 1999, 62, 976-983; (c) E. Clinquart, Bull. Acad. R. Med. Belg., 1929, 9, 627-635.

8 (a) S. J. Holt and V. Petrow, J. Chem. Soc., 1948, 922-924; (b) L. Kaczmarek, R. Balicki, P. Nantka-Namirski, W. PeczynskaCzoch and M. Modarsski, Arch. Pharm., 1988, 321, 463-467; (c) W. Peczynska-Czoch, F. Pognan, L. Kaczmarek and
J. Boratynski, J. Med. Chem., 1994, 37, 3503-3510; (d) K. Kamienska-Trela, L. Kania and L. Kaczmarek, THEOCHEM, 1995, 347, 467-476; (e) S. P. Lathrop, M. Pompeo, W.-T. T. Chang and M. Movassaghi, J. Am. Chem. Soc., 2016, 138, 7763-7769; (f) J. Belmar and R. L. Funk, J. Am. Chem. Soc., 2012, 134, 16941-16943; (g) K. Popov, A. Hoang and P. Somfai, Angew. Chem., 2016, 128, 1833-1836.

9 (a) A. B. J. Bracca, D. A. Heredia, E. L. Larghi and T. S. Kaufman, Eur. J. Org. Chem., 2014, 7979-8003; (b) E. L. Larghi, A. B. J. Bracca, A. A. Arroyo Aguilar, D. A. Heredia, J. L. Pergomet, S. O. Simonetti and T. S. Kaufman, Curr. Top. Med. Chem., 2015, 17, 1683-1707. 10 (a) R. Engqvist and J. Bergman, Org. Prep. Proced. Int., 2004, 36, 386-390; (b) S. Sharma and B. Kundu, Tetrahedron Lett., 2008, 49, 7062-7065; (c) P. T. Parvatkar and S. G. Tilve, Tetrahedron Lett., 2011, 52, 6594-6596; (d) G. A. Kraus and H. Guo, Tetrahedron Lett., 2010, 51, 4137-4139; (e) M. K. Vecchione, A. X. Sun and D. Seidel, Chem. Sci., 2011, 2, 2178-2181.

11 (a) T. Dhanabal, R. Sangeetha and P. S. Mohan, Tetrahedron, 2006, 62, 6258-6263; (b) G. Timari, T. Soos and G. Hajós, Synlett, 1997, 1067-1068; (c) S. Hostyn, K. A. Tehrani, F. Lemière, V. Smout and B. U. W. Maes, Tetrahedron, 2011, 67, 655-659.

12 (a) C. Shi, Q. Zhang and K. K. Wang, J. Org. Chem., 1999, 64, 925-932; (b) T.-L. Ho and D.-G. Jou, Helv. Chim. Acta, 2002, 85, 3823-3827; (c) P. T. Parvatkar, P. S. Parameswarana and S. G. Tilve, Tetrahedron Lett., 2007, 48, 7870-7872; (d) M. J. Haddadin, R. M. B. Zerdan, M. J. Kurth and J. C. Fettinger, Org. Lett., 2010, 12, 5502-8527; (e) D. Basavaiah and D. Mallikarjuna Reddy, Org. Biomol. Chem., 2012, 10, 8774-8777; (f) P. Pitchai, M. Yathisateelan, A. Nepolraj and R. M. Gengan, Indian J. Biochem. Biophys., 2015, 54, 1290-1292; (g) P. M. Fresneda, P. Molina and S. Delgado, Tetrahedron Lett., 1999, 40, 7275-7278; (h) P. M. Fresneda, P. Molina and S. Delgado, Tetrahedron, 2001, 57, 6197-6202; (i) T. H. M. Jonckers, S. van Miert, K. Cimanga, C. Bailly, P. Colson, M.-C. De Pauw-Gillet, H. van den Heuvel, M. Claeys, F. Lemière, E. L. Esmans, J. Rozenski, L. Quirijnen, L. Maes, R. Dommisse, G. L. F. Lemière, A. Vlietinck and L. Pieters, J. Med. Chem., 2002, 45, 3497-3508; (j) M. Miller, J. C. Vogel, W. Tsang, A. Merrit and D. J. Procter, Org. Biomol. Chem., 2009, 7, 589-597.

13 Formal total syntheses. From indoles: (a) F. Portela-Cubillo, J. S. Scott and J. C. Walton, J. Org. Chem., 2008, 73, 55585565; (b) H. K. Kadam, P. T. Parvatkar and S. G. Tilve, Synthesis, 2012, 44, 1339-1342; (c) G. S. M. Sundaram, C. Venkatesh, U. K. Syam Kumar, H. Ila and H. Junjappa, J. Org. Chem., 2004, 69, 5760-5762; (d) P. T. Parvatkar, P. S. Parameswaran and S. G. Tilve, J. Org. Chem., 2009, 74, 8369-8372; $\quad(e) \quad$ R. Ghorbani-Vaghei and S. M. Malaekehpoor, Tetrahedron Lett., 2012, 53, 47514753; (f) H. K. Kadam and S. G. Tilve, J. Heterocycl. Chem., 2016, 53, 2066-2069; From quinolones: $(g)$ B. Bogányi and J. Kámán, Tetrahedron, 2013, 69, 9512-9519. From 
benzenoids: ( $h$ ) M. Alajarín, P. Molina and A. Vidal, J. Nat. Prod., 1997, 60, 747-748.

14 (a) O. Amiri-Attou, T. Terme and P. Vanelle, Synlett, 2005, 3047-3050; (b) S. Ali, Y.-X. Li, S. Anwar, F. Yang, Z.-S. Chen and Y.-M. Liang, J. Org. Chem., 2012, 77, 424-431; (c) Z. Yan, C. Wan, J. Wan and Z. Wang, Org. Biomol. Chem., 2016, 14, 4405-4408; (d) S. Badigenchala, V. Rajeshkumar and G. Sekar, Org. Biomol. Chem., 2016, 14, 2297-2305.

15 S. O. Simonetti, E. L. Larghi, A. B. J. Bracca and T. S. Kaufman, Org. Biomol. Chem., 2012, 10, 4124-4134.

16 (a) R. H. Dave and B. D. Hosangadi, Tetrahedron, 1999, 55, 11295-11308; (b) A.-H. Li, E. Ahmed, X. Chen, M. Cox, A. P. Crew, H.-Q. Dong, M. Jin, L. Ma, B. Panicker, K. W. Siu, A. G. Steinig, K. M. Stolz, P. A. R. Tavares, B. Volk, Q. Weng, D. Werner and M. J. Mulvihill, Org. Biomol. Chem., 2007, 5, 61-64; (c) C. Zhang, C. Kanta De and D. Seidel, Org. Synth., 2012, 89, 274-282.

17 (a) S. Chandrappa, T. Vinaya, T. Ramakrishnappa and K. S. Rangappa, Synlett, 2010, 3019-3022; (b) B. Gabriele, G. Salerno, L. Veltri, M. Costa and C. Massera, Eur. J. Org. Chem., 2001, 4607-4613; (c) X. Pang, Z. Lou, M. Li, L. Wen and C. Chen, Eur. J. Org. Chem., 2015, 3361-3369.

18 (a) S. Bhandari and S. Ray, Synth. Commun., 1998, 28, 765771; (b) G. Bartoli, M. Bosco, A. Carlone, R. Dalpozzo, E. Marcantoni, P. Melchiorre and L. Sambri, Synthesis, 2007, 3489-3496; (c) J. S. Carey, D. Laffan, C. Thomson and M. T. Williams, Org. Biomol. Chem., 2006, 4, 2337-2347; (d) K. Alfonsi, J. Colberg, P. J. Dunn, T. Fevig, S. Jennings, T. A. Johnson, H. P. Kleine, C. Knight, M. A. Nagy, D. A. Perry and M. Stefaniak, Green Chem., 2008, 10, 31-36; (e) H. Ueki, T. K. Ellis, M. A. Khan and V. A. Soloshonok, Tetrahedron, 2003, 59, 7301-7306; (f) R. J. Ternansky, C. L. Jordan, J. A. Eudaly and J. S. Kasher, J. Med. Chem., 1993, 36, 2332-2334.

19 M. L. Nielsen, J. V. Pustinger Jr and J. Strobel, J. Chem. Eng. Data, 1964, 9, 167-170.

20 (a) A. V. Aksenov, A. N. Smirnov, N. A. Aksenov, I. V. Aksenova, J. P. Matheny and M. Rubin, RSC Adv., 2015, 5, 8647-8656; (b) C. Capello, U. Fischer and K. Hungerbühler, Green Chem., 2007, 9, 927-934.

21 (a) K. K. Park and J. Y. Jung, Heterocycles, 2005, 65, 20952105; (b) M. Rowley, J. J. Kulagowski, A. P. Watt, D. Rathbone, G. I. Stevenson, R. W. Carling, R. Baker, G. R. Marshall, J. A. Kemp, A. C. Foster, S. Grimwood, R. Hargreaves, C. Hurley, K. L. Saywell, M. D. Tricklebank and P. D. Leeson, J. Med. Chem., 1997, 40, 4053-4068.

22 (a) D. V. Kravchenko, Y. A. Kuzovkova, V. M. Kysil, S. E. Tkachenko, S. Maliarchouk, I. M. Okun, K. V. Balakin and A. V. Ivachtchenko, J. Med. Chem., 2005, 48, 36803683; (b) V. V. Mulwad and M. V. Lohar, J. Heterocycl. Chem., 2003, 42, 2567-2572.

23 (a) X. Bu, L. W. Deady and W. A. Denny, Aust. J. Chem., 2000, 53, 143-147; (b) Ionic Liquids in Synthesis, ed. P.
Wasserscheid and T. Welton, Wiley-VCH, Weinheim, Germany, 2nd edn, 2008, pp. 319-321.

24 R. Oberkobusch, Chem. Ber., 1953, 86, 975-978.

25 (a) S. Yu, Y. Li, X. Zhou, H. Wang, L. Kong and X. Li, Org. Lett., 2016, 18, 2812-2815; (b) L. Shi and B. Wang, Org. Lett., 2016, 18, 2820-2823; (c) A. Khorshidi and K. Tabatabaeian, J. Mol. Catal. A: Chem., 2011, 344, 128131; (d) C. Venkatesh, G. S. M. Sundaram, H. Ila and H. Junjappa, J. Org. Chem., 2006, 71, 1280-1283.

26 S. T. Gadge, A. Mishra, A. L. Gajengi, N. V. Shahi and B. M. Bhanage, RSC Adv., 2014, 4, 50271-50276.

27 (a) R. Bernini, F. Crisante and M. C. Ginnasi, Molecules, 2011, 16, 1418-1425; (b) W.-C. Shieh, S. Dell and O. Repic, Org. Lett., 2001, 3, 4279-4281.

28 (a) P. Tundo, L. Rossi and A. Loris, J. Org. Chem., 2005, 70, 2219-2224; (b) P. Tundo, Pure Appl. Chem., 2001, 73, 11171124.

29 (a) E. Chrystiuk and A. Williams, J. Am. Chem. Soc., 1987, 109, 3040-3046; (b) T. H. Black, S. M. Arrivo, J. S. Schumm and J. M. Knobeloch, J. Org. Chem., 1987, 52, 5425-5430.

30 (a) J. Fossey, A. Loupy and H. Strszelecka, Tetrahedron, 1981, 37, 1935-1941; (b) M. F. Pereira, V. Thiéry and T. Besson, Tetrahedron Lett., 2007, 48, 7657-7659; (c) M. J. Reyes, F. Delgado, M. L. Izquierdo and J. Alvarez-Builla, Tetrahedron, 2002, 58, 8573-8579; (d) H. Wu, F. Xue, X. Xiao and Y. Qin, J. Am. Chem. Soc., 2010, 132, 1405214054.

31 (a) L. G. Mardenborough, X. Y. Zhu, P. Fan, M. R. Jacob, S. I. Khan, L. A. Walker and S. Y. Ablordeppey, Bioorg. Med. Chem., 2005, 13, 3955-3963; (b) T.-L. Ho and D.-G. Jou, Helv. Chim. Acta, 2002, 85, 3823-3827; (c) T. K. Lai, A. Chatterjee, J. Banerji, D. Sarkar and N. Chattopadhyay, Helv. Chim. Acta, 2008, 91, 1975-1983.

32 (a) W.-C. Shieh, S. Dell, A. Bach, O. Repic and T. J. Blacklock, J. Org. Chem., 2003, 68, 1954-1957; (b) S. Ouk, S. Thiébaud, E. Borredon and B. Chabaud, Synth. Commun., 2005, 35, 3021-3026.

33 (a) T. N. Glasnov, J. D. Holbrey, C. O. Kappe, K. R. Seddon and T. Yan, Green Chem., 2012, 14, 3071-3076; (b) M. L. Laurila, N. A. Magnus and M. A. Staszak, Org. Process Res. Dev., 2009, 13, 1199-1201; (c) H. Yan, L. Zeng, Y. Xie, Y. Cui, L. Ye and S. Tu, Res. Chem. Intermed., 2016, 42, 5951-5960.

34 (a) N. Vôute, D. Philp, A. M. Z. Slawin and N. J. Westwood, Org. Biomol. Chem., 2010, 8, 442-450; (b) Y.-L. Chen, H.-M. Hung, C.-M. Lu, K.-C. Li and C.-C. Tzeng, Bioorg. Med. Chem., 2004, 12, 6539-6546; (c) H. Mastalarz, R. Jasztold-Howorko, F. Rulko, A. Croisy and D. Carrez, Arch. Pharm., 2004, 337, 434-439.

35 H. Wagner, S. Bladt and V. Rickl. Drug Analysis: A Thin Layer Chromatography Atlas, Springer, Heidelberg, Germany, 2nd edn. 2009, p. 360 . 